\title{
Promoter region methylation does not account for the frequent loss of expression of the Fas gene in colorectal carcinoma
}

\author{
LM Butler ${ }^{1}$, A Dobrovic ${ }^{2,3}$, T Bianco $^{2,3}$ and PA Cowled ${ }^{1}$ \\ Departments of ${ }^{1}$ Surger and ${ }^{2}$ Medicine, The University of Adelaide, and ${ }^{3}$ Haematology-Oncology, The Queen Elizabeth Hospital, Woodville, South Australia \\ 5011, Australia
}

\begin{abstract}
Summary Expression of the apoptosis-promoting Fas gene is frequently reduced or lost during the development of colorectal carcinoma. However, loss of heterozygosity at the Fas locus or Fas gene rearrangements do not account for the loss of expression of Fas, raising the possibility that methylation of the Fas promoter may inhibit gene expression in colorectal carcinomas. We have examined the Fas promoter region $\mathrm{CpG}$ island for evidence of hypermethylation in colorectal tumours. Forty-seven specimens of colorectal adenoma and carcinoma, as well as six samples of normal colonic mucosa, were examined by Southern blotting for methylation at Hpall and Cfol sites in this region. No methylation was detected in any of the specimens, suggesting that hypermethylation is not primarily responsible for the loss of expression of the Fas gene during colorectal tumorigenesis. (C) 2000 Cancer Research Campaign
\end{abstract}

Keywords: CpG island; methylation; gene silencing; apoptosis

There is increasing evidence that de novo methylation of promoter-associated $\mathrm{CpG}$ islands, contributes to the alteration of gene expression in cancer (reviewed by Baylin et al, 1998). During the development of colon cancer, methylation of $\mathrm{CpG}$ islands has been reported in a number of genes including the calcitonin gene (Silverman et al, 1989), the oestrogen receptor gene (Issa et al, 1994), the mismatch repair gene $h M L H 1$ (Kane et al, 1997), the $M y o D$ gene (Myf-3) (Iacopetta et al, 1997) and the $A P C$ gene (Hiltunen et al, 1997). More recently, a progressive increase in methylation was also detected at some of these loci in normal colonic mucosa as a consequence of aging (Ahuja et al, 1998). In the studies that examined gene expression, methylation of the $\mathrm{CpG}$ islands was associated with gene silencing.

In the colon, apoptosis contributes to the homeostasis of the epithelial layer of the mucosa, which has a rapid rate of cell turnover (Hall et al, 1994). Apoptosis is also responsible for the removal of colonocytes with potentially oncogenic DNA damage. Resistance of colonocytes to apoptosis may allow hyperproliferation, accumulation of oncogenic mutations and prevent killing of malignant cells by chemotherapeutic agents. Abnormal patterns of expression of a number of apoptosis-related genes have been reported in both benign and malignant colonic tumours (reviewed in Butler et al, 1999); however, molecular mediators of resistance to apoptosis remain to be identified.

The Fas antigen is a widely expressed cell surface receptor. Ligation of Fas by its endogenous ligand or by agonistic antibodies, triggers rapid apoptosis (Trauth et al, 1989; Yonehara et al, 1989). The epithelial layer of the normal colonic mucosa expresses Fas protein at high levels from the bottom of the crypts to the

Received 22 February 1999

Revised 22 June 1999

Accepted 7 July 1999

Correspondence to: PA Cowled luminal surface (Leithauser et al, 1993; Moller et al, 1994). Expression of Fas in the colon is progressively reduced during the transformation of normal epithelium to benign neoplasms, adenocarcinomas and ultimately, to metastases (Leithauser et al, 1993; Moller et al, 1994). Loss of Fas activity could be a contributing factor to the reduction in apoptotic capacity of colonic carcinomas. In a previous study (Butler et al, 1998), we showed that the loss of expression of Fas protein was reflected in a loss of Fas mRNA in the majority of samples of colorectal carcinoma. However, allelic loss of the Fas gene was a relatively rare event, being detected in only $16 \%$ of carcinomas and reflecting the rate of loss of the entire chromosome arm, $10 \mathrm{q}$, in colorectal carcinoma (Vogelstein et al, 1989). Similarly, gross gene rearrangements were not detected in any of the colorectal carcinomas, raising the possibility that epigenetic events, including DNA methylation, could be responsible for the loss of expression of Fas.

The human Fas gene contains a 650 bp GC-rich $\mathrm{CpG}$ island spanning the $5^{\prime}$ regulatory region and the first exon (Behrmann et al, 1994; Cheng et al, 1995; Rudert et al, 1995), suggesting that transcription of the gene may be regulated by methylation of the $\mathrm{CpG}$ cytosine residues. The aim of this study was to determine the methylation status of the promoter and exon 1 of the Fas gene in DNA isolated from colorectal tumours with varying levels of expression of Fas mRNA.

\section{MATERIALS AND METHODS}

\section{Patients and samples}

Forty-seven specimens of primary colonic or rectal tumours, consisting of six adenomas and 41 carcinomas plus six samples of macroscopically normal colonic mucosa, were obtained with informed consent from 44 patients undergoing colonic resections. The Dukes grades of the carcinomas are shown in Table 1. 
Table 1 Clinical stages of carcinomas analysed for methylation status of the Fas gene

\begin{tabular}{lc}
\hline Dukes' grade & Number of specimens \\
\hline A & 3 \\
B & 23 \\
C & 12 \\
D & 2 \\
Unclassified & 1 \\
\hline
\end{tabular}

\section{Construction of a Fas Probe}

PCR primers 5Prom1 (5'-TCCTGTACCCAGGCAGGAC) and 3Prom2 (5'-ATCCCCGGGACTAAGACGG) were designed to amplify a 655 base pair (bp) region spanning part of the promoter and exon one of the human Fas gene (Figure 1). The probe was amplified from normal genomic DNA by an initial denaturation of 5 min at $94^{\circ} \mathrm{C}$, followed by 35 cycles of denaturation for $1 \mathrm{~min}$ at $94^{\circ} \mathrm{C}$, annealing for $1 \mathrm{~min}$ at $58^{\circ} \mathrm{C}$ and extension for $90 \mathrm{~s}$ at $72^{\circ} \mathrm{C}$; with a final extension of $5 \mathrm{~min}$ at $72^{\circ} \mathrm{C}$. The PCR product was cloned into the pGEM-T plasmid vector (Promega, Madison, WI, USA) and the identity of the product confirmed by DNA sequencing. To generate a probe for Southern blotting, the Fas gene insert was amplified from the Fas-pGEM plasmid using 5Prom1 and 3Prom2 primers, under the same amplification conditions.

\section{Southern blotting using methylation-sensitive restriction enzymes}

Ten micrograms of genomic DNA, isolated from colorectal tumours or normal mucosa, was digested with TaqI (New England Biolabs, Beverley, MA, USA), for $3 \mathrm{~h}$ or overnight at $65^{\circ} \mathrm{C}$. DNA was ethanol-precipitated before re-digesting with HpaII, MspI (New England Biolabs) or CfoI (Boehringer Mannheim). Digests were electrophoresed through $1.8 \%$ or $1.5 \%$ agarose gels and blotted onto Genescreen Plus membranes (Dupont, Boston, MA, USA). Membranes were hybridized with the ${ }^{32} \mathrm{P}$-labelled probe for $16 \mathrm{~h}$ at $42^{\circ} \mathrm{C}$ in $50 \%$ formamide, washed to a final stringency of $0.1 \times \mathrm{SSC}$ (standard saline citrate) and $0.1 \%$ sodium dodecyl sulphate (SDS) at $68^{\circ} \mathrm{C}$ and the hybridization signals detected by autoradiography.

\section{RESULTS}

The methylation status of the $5^{\prime}$ regulatory region and exon 1 of the Fas gene was initially examined by Southern blotting of DNA following digestion with the restriction enzymes MspI and HpaII. Both of these enzymes recognize the same DNA sequence (CCGG); however, HpaII will not cut the sequence if the internal cytosine residue is methylated. Six HpaII/MspI sites are present in the region spanning the three putative transcriptional start sites within the first exon of the Fas gene (Cheng et al, 1995) (Figure $1)$. A second enzyme, $C f o I$, was also used to assess the methylation status of a further five $\mathrm{CpG}$ sites in this region (Figure 1). CfoI cleaves the sequence GCGC, but is inactive if the central $\mathrm{C}$ is methylated. A Fas gene probe was generated by polymerase chain reaction (PCR) amplification and its identity confirmed by sequencing (Cheng et al, 1995).

The DNA was initially digested with TaqI, which flanked five of the HpaII sites as well as four of the $C f o$ I sites. The recognition sequence of TaqI (TCGA) contains a CpG dinucleotide; however, TaqI is not methylation-sensitive (Streeck, 1980). Digestion of normal DNA (isolated from peripheral blood lymphocytes) with the flanking enzyme, TaqI, alone, produced a band of $1 \mathrm{~kb}$ when hybridized with the Fas probe (Figures 2 and 3). A second band of approximately $5 \mathrm{~kb}$ in size was also detected, arising from binding of the probe to sequences upstream of the TaqI site in the Fas promoter.

When the TaqI-digested normal DNA was digested with MspI, bands of $300 \mathrm{bp}$ and $115 \mathrm{bp}$ were observed, as well as the $5 \mathrm{~kb}$
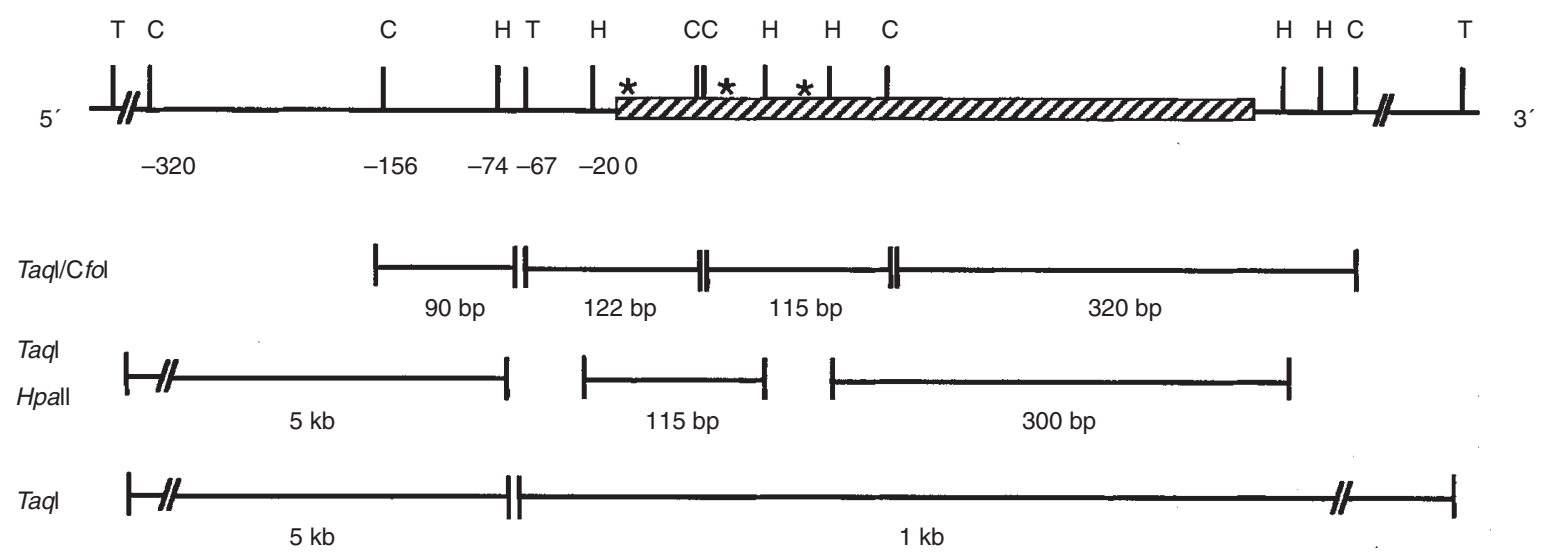

Figure 1 Restriction map of the $5^{\prime}$ regulatory region and exon 1 of the human Fas gene. $\mathrm{T}=$ Taql site, $\mathrm{H}=\mathrm{Hpall}$ site, $\mathrm{C}=\mathrm{Cfol}$ site. The asterisks denote the major three transcription start sites (Cheng et al, 1995) and the hatched box denotes exon 1. The sizes of the major DNA restriction fragments are shown underneath the map and the location of the $655 \mathrm{bp}$ Fas probe is shown above the map. The $5^{\prime}$ end of the probe detects an approximately $5 \mathrm{~kb}$ Taql fragment. Only the 1957 bp section directly upstream of the first transcription start site has been sequenced (Cheng et al, 1995, Rudert et al, 1995) 


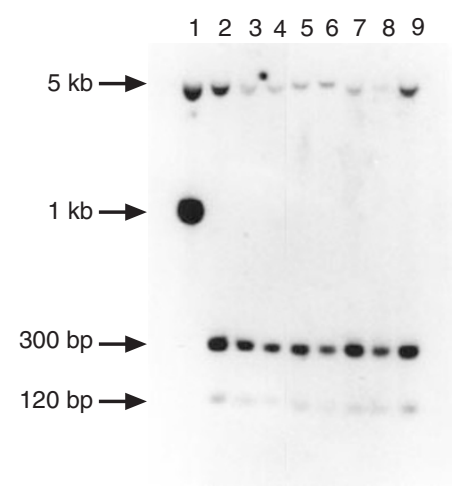

Figure 2 Southern analysis of the Fas gene promoter from colorectal tumours for changes in methylation. The blot was hybridized with a $655 \mathrm{bp}$ probe spanning five Hpall sites, in the promoter and first intron of the human Fas gene. Lane 1 contains normal genomic DNA digested with Taql, lane 2 contains the same DNA digested with Taql and Mspl, while lanes 3-9 contain individual samples of DNA from colonic tumours, digested with Taql and Hpall

band previously observed following digestion with TaqI alone (Figure 2). According to a restriction map of the Fas promoter and exon 1, digestion of the $1 \mathrm{~kb} T a q \mathrm{I}$ fragment with $M s p \mathrm{I}$ and probing with the 655 bp Fas probe, should produce DNA fragments of 300 , $115,47,43$ and 28 bp (Figure 1). The smallest three fragments could not be detected by Southern analysis. The methylation status of the $1 \mathrm{~kb}$ region could then be determined by digestion of DNA with TaqI and HpaII. If the sequence was fully methylated, HpaII would not cut the DNA and the banding pattern would be the same as that of TaqI alone. An unmethylated sequence would be completely digested by HpaII and the banding pattern would be the same as digestion with TaqI and MspI. A partially methylated sequence would give rise to bands of intermediate size.

There are no MspI sites in the 1957 bp of known sequence upstream of the first transcription start site (Cheng et al, 1995; Rudert et al, 1995). Since there was no detectable change in the size of the $5 \mathrm{~kb}$ band following digestion with both TaqI and MspI, it can be deduced that there are probably no $M s p$ I sites in the undefined upstream sequence (Figure 1).

Forty-eight samples of DNA isolated from colonic carcinomas plus six adenomas were analysed for methylation of the HpaII sites. These samples included a range of tumour grades (Table 1). Two of the patients had both an adenoma and carcinoma analysed and one patient had both a primary tumour and a metastatic deposit. Digestion of the DNA samples with TaqI and HpaII produced the same banding pattern as digestion with TaqI and MspI. The HpaII sites were therefore not methylated in any of the tumour samples analysed (Figure 2). There was also no evidence of Fas methylation in six samples of DNA isolated from normal colorectal mucosa.

Nineteen of the carcinomas were also assessed for methylation at the CfoI sites (Figure 3), however, none of these sites were methylated in any of the tumours tested. Digestion of DNA with $T a q \mathrm{I}$ and $C f o \mathrm{I}$ gives rise to bands of $320,122,115$ and $90 \mathrm{bp}$ in size. The 90-bp band was detected in the more-heavily-loaded tracks and the 122 and $115 \mathrm{bp}$ bands coincided on the blots. No $5 \mathrm{~kb}$ band was detected in CfoI/TaqI-digested DNA, confirming that the $C f o$ I site located 156 bp upstream of the first transcription start site is unmethylated in all samples tested. There is a further

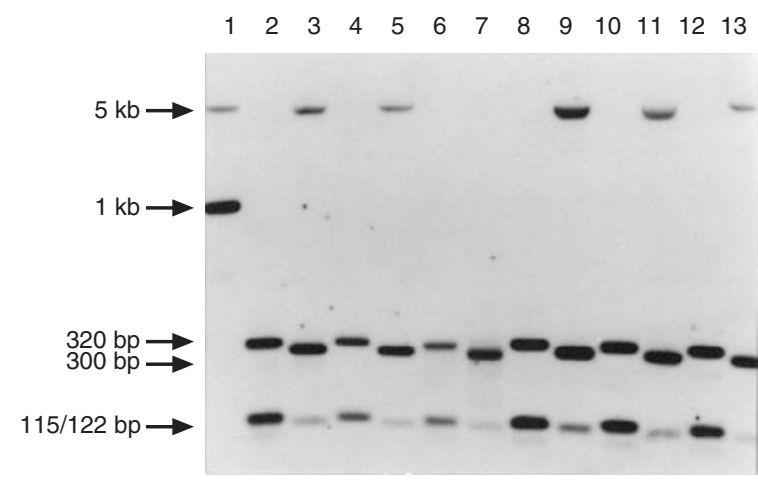

Figure 3 Southern analysis of the Fas gene promoter from colorectal tumours for changes in methylation. The blot was hybridized with a $655 \mathrm{bp}$ probe spanning five Hpall sites and four $\mathrm{Cfol}$ sites in the promoter and first intron of the human Fas gene. Lane 1 contains genomic DNA digested with Taql only and lanes $2-13$ contain samples of DNA from colonic tumours, digested with $\mathrm{Taql}$ and $\mathrm{Cfol}$ (odd numbered lanes) or Taql and Hpall (even numbered lanes)

CfoI site 320 bp upstream of the first transcription start site (Figure 1) but the methylation status of this site can not be analysed as the probe does not cover this region.

Seventeen of the tumours used in this study have previously been analysed by Northern blotting for expression of Fas mRNA (Butler et al, 1998). Nine of the tumours expressed normal levels of Fas mRNA, five had reduced levels and, in two samples, Fas mRNA could not be detected. This study probably underestimated the loss of Fas as most tumours also contained normal tissue.

\section{DISCUSSION}

Cancer arises from the accumulation of multiple genetic and epigenetic events in cellular DNA. These alterations can cause the aberrant expression of genes involved in the regulation of cell death, adhesion and proliferation. Methylation of $\mathrm{CpG}$ residues in the $5^{\prime}$ regulatory regions of tumour suppressor genes may be a mechanism by which cellular proliferation can be deregulated without genetic mutations (reviewed in Baylin et al, 1998). In colon cancer, alterations in global methylation patterns are among the earliest abnormalities to occur during the development of the disease (Goelz et al, 1985). The studies presented above indicate that the Fas gene promoter is consistently unmethylated in colorectal tumours and normal mucosa. This suggests that methylation of the Fas promoter is not involved in the transcriptional silencing of the Fas gene in colon tumours.

Screening samples of DNA for cytosine methylation using restriction enzymes only examines a proportion of the total $\mathrm{CpG}$ dinucleotides in a $\mathrm{CpG}$ island. There are $31 \mathrm{CpG}$ sites in the 655 bp region of the Fas promoter and exon 1 spanned by the Fas probe in the present study (Cheng et al, 1995). The HpaII and CfoI sites examined in the present study represent nine of them, or $29 \%$. One of the HpaII sites in the promoter region is $20 \mathrm{bp}$ upstream of the first transcription start site. Any $\mathrm{CpG}$ methylation at this site might interfere with binding of RNA polymerase and inhibit transcription of the Fas gene. It is possible that de novo methylation of the Fas promoter region does not involve all $\mathrm{CpG}$ sites and that selective methylation of the $\mathrm{CpG}$ island is sufficient for the regulation of transcription factor binding. Further studies using other 
methodologies, including genomic sequencing using bisulphite modification, which determines the methylation status of all cytosines in a sequence (Frommer et al, 1992), are required to totally exclude methylation that is restricted to a small region.

Other mechanisms must therefore be considered to account for the frequent loss of expression of the Fas protein in colorectal carcinoma. One mechanism for loss of Fas expression is that expression or function of an essential transcription factor has been altered. The promoter region of the Fas gene contains binding sites for several transcriptional regulatory factors, including c-myb, p53, NF- $\mathrm{KB}$ and Sp-1 (Behrmann et al, 1994; Cheng et al, 1995; Rudert et al, 1995). An essential role has recently been demon-

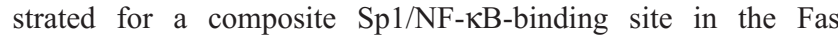
promoter, in activating the expression of Fas mRNA in Jurkat cells (Chan et al, 1999). Futher studies will be required to investigate the hypothesis that defects in Sp1/NF- $\mathrm{KB}$ activity could account for loss of expression of Fas in colorectal carcinomas.

A potential candidate for the regulation of the activity of the Fas gene is p53, which, when expressed in tumour cells, induces the expression of Fas mRNA (Owen-Schaub et al, 1995). Expression of wild-type p53 in colon cancer cells renders them sensitive to Fas-mediated apoptosis (Tamura et al, 1995) and certain genotoxic treatments induce cell surface expression of Fas only in cells with wild-type p53 genes (Matsumoto et al, 1996; Muller et al, 1997; Reap et al, 1997; Reinke and Lozano, 1997; Sheard et al, 1997). Taken together, these studies indicate that the Fas gene is a target of p53-mediated transactivation. Inactivation of the $p 53$ gene by mutation and/or allelic loss occurs in up to $75 \%$ of colorectal carcinomas (Baker et al, 1990), a similar frequency to loss of Fas expression (Moller et al, 1994; Butler et al, 1998). Loss of Fas expression may therefore be a consequence of p53 inactivation in most colorectal tumours. The activity of histone acetyltransferases and deacetylases is also vital in regulating gene regulation (reviewed in Kuo and Allis, 1998) and alterations in the activity of these enzymes might also play a role in the silencing of the Fas gene in colorectal carcinoma. Further studies are required to define the molecular mechanisms controlling expression of the Fas gene and to determine the nature and significance of the defects in Fas expression in colorectal carcinoma.

\section{ACKNOWLEDGEMENTS}

LMB was supported by an Australian Postgraduate Research Scholarship and by supplementary funding from The Queen Elizabeth Hospital Research Foundation. TB was supported by an Australian Postgraduate Research Scholarship. We wish to thank Mr Peter Hewett for providing the clinical samples.

\section{REFERENCES}

Ahuja N, Li Q, Mohan AL, Baylin SB and Issa J-PJ (1998) Aging and DNA methylation in colorectal mucosa and cancer. Cancer Res 58: 5489-5494

Baker SJ, Markowitz S, Fearon ER, Willson JKV and Vogelstein B (1990) Suppression of human colorectal carcinoma cell growth by wild-type p53. Science 249: 912-915

Baylin SB, Herman JG, Graff JR, Vertino PM and Issa J-P (1998) Alterations in DNA methylation: a fundamental aspect of neoplasia. Adv Cancer Res $\mathbf{7 2}$ : 141-196

Behrmann I, Walczak H and Krammer PH (1994) Structure of the human APO-1 gene. Eur J Immunol 24: 3057-3062

Butler LM, Hewett PJ, Butler WJ and Cowled PA (1998) Down-regulation of Fas gene expression in colon cancer is not a result of allelic loss or gene rearrangement. Br J Cancer 77: 1454-1459
Butler LM, Hewett PJ, Fitridge RA and Cowled PA (1999) Deregulation of apoptosis in colorectal cancer: theoretical and therapeutic implications. Aust NZ J Surg 69: 88-94

Chan H, Bartos DP and Owen-Schaub LB (1999) Activation-dependent transcriptional regulation of the human Fas promoter requires NF-kappaB p50-p65 recruitment. Mol Cell Biol 19: 2098-2108

Cheng J, Liu C, Koopman WJ and Mountz JD (1995) Characterization of human Fas gene. J Immunol 154: 1239-1245

Frommer M, McDonald LE, Millar DS, Collis CM, Watt F, Grigg GW, Molloy PL and Paul CL (1992) A genomic sequencing protocol that yields a positive display of 5-methylcytosine residues in individual DNA strands. Proc Natl Acad Sci USA 89: 1827-1831

Goelz SE, Vogelstein B, Hamilton SR and Feinberg AP (1985) Hypomethylation of DNA from benign and malignant human colon neoplasms. Science $\mathbf{2 2 8}$ : 187-190

Hall PA, Coates PJ, Ansari B and Hopwood D (1994) Regulation of cell number in the mammalian gastrointestinal tract: the importance of apoptosis. J Cell Sci 107: 3569-3577

Hiltunen MO, Alhonen L, Koistinaho J, Myöhänen S, Pääkkönen M, Marin S, Kosma V-M and Jänne J (1997) Hypermethylation of the APC (adenomatous polyposis coli) gene promoter region in human colorectal carcinoma. Int $J$ Cancer 70: 644-648

Iacopetta BJ, Harmon D, Spagnolo DV, House AK and Kay PH (1997) Hypermethylation of the $M y f-3$ gene in human colorectal cancer. Anticancer Res 17: 429-432

Issa J-P, Ottaviano YL, Celano P, Hamilton SR, Davidson NE and Baylin SB (1994) Methylation of the oestrogen receptor $\mathrm{CpG}$ island links ageing and neoplasia in human colon. Nat Genet 7: 536-540

Kane MF, Loda M, Gaida GM, Lipman J, Mishra R, Goldman H, Jessup JM and Kolodner R (1997) Methylation of the $h M L H 1$ promoter correlates with lack of expression of hMLH1 in sporadic colon tumors and mismatch repair-defective human tumor cell lines. Cancer Res 57: 808-811

Kuo MH and Allis CD (1998) Roles of histone acetyltransferases and deacetylases in gene regulation. Bioessays 20: 615-626

Leithäuser F, Dhein J, Mechtersheimer G, Koretz K, Brüderlein S, Henne C, Schmidt A, Debatin K-M, Krammer PH and Möller P (1993) Constitutive and induced expression of APO-1, a new member of the nerve growth factor/tumor necrosis factor receptor superfamily, in normal and neoplastic cells. Lab Invest 69: 415-429

Matsumoto Y, Hayakawa A, Tamada Y, Mori H and Ohashi M (1996) Upregulated expression of Fas antigen on cultured human keratinocytes with induction of apoptosis by cisplatin. Arch Dermatol Res 288: 267-269

Möller P, Koretz K, Leithauser F, Brüderlein S, Henne C, Quentmeier A and Krammer PH (1994) Expression of APO-1 (CD95), a member of the NGF/TNF receptor superfamily, in normal and neoplastic colon epithelium. Int J Cancer 57: 371-377

Muller M, Strand S, Hug H, Heinemann E-M, Walczak H, Hofmann WJ, Stremmel W, Krammer PH and Galle PR (1997) Drug-induced apoptosis in hepatoma cells is mediated by the CD95 (APO-1/Fas) receptor/ligand system and involves activation of wild-type p53. J Clin Invest 99: 403-413

Owen-Schaub LB, Zhang W, Cusack JC, Angelo LS, Santee SM, Fujiwara T, Roth JA, Deisseroth AB, Zhang W-W, Kruzel E and Radinsky R (1995) Wild-type human 53 and a temperature-sensitive mutant induce Fas/APO-1 expression. Mol Cell Biol 15: 3032-3040

Reap EA, Roof K, Maynor K, Borrero M, Booker J and Cohen PL (1997) Radiation and stress-induced apoptosis: a role for Fas/Fas ligand interactions. Proc Natl Acad Sci USA 94: 5750-5755

Reinke V and Lozano G (1997) The p53 targets $m d m 2$ and Fas are not required as mediators of apoptosis in vivo. Oncogene 15: 1527-1534

Rudert F, Visser E, Forbes L, Lindridge E, Wang Y and Watson J (1995) Identification of a silencer, enhancer, and basal promoter region in the human CD95 (Fas/APO-1) gene. DNA Cell Biol 14: 931-937

Sheard MA, Vojtesek B, Janakova L, Kovarik J and Zaloudik J (1997) Up-regulation of Fas (CD95) in human $\mathrm{p} 53^{\text {wild-type }}$ cancer cells treated with ionizing radiation. Int $J$ Cancer 73: 757-762

Silverman AL, Park J-G, Hamilton SR, Gazdar AF, Luk GD and Baylin SB (1989) Abnormal methylation of the calcitonin gene in human colonic neoplasms. Cancer Res 49: 3468-3473

Streeck RE (1980) Single-strand and double-strand cleavage at half-modified and fully modified recognition sites for the restriction nucleases $\operatorname{Sau} 3 A$ and $T a q \mathrm{I}$. Gene 12: 267-275

Tamura T, Aoyama N, Saya H, Haga H, Futami S, Miyamoto M, Koh T, Ariyasu T, Tachi M, Kasuga M and Takahashi R (1995) Induction of Fas-mediated apoptosis in p53-transfected human colon carcinoma cells. Oncogene 11: 1939-1946 
Trauth BC, Klas C, Peters AMJ, Matzku S, Möller P, Falk W, Debatin K-M and Krammer PH (1989) Monoclonal antibody-mediated tumor regression by induction of apoptosis. Science 245: 301-304

Vogelstein B, Fearon ER, Kern SE, Hamilton SR, Preisinger AC, Nakamura Y and White R (1989) Allelotype of colorectal carcinomas. Science 244: 207-211
Yonehara S, Ishii A and Yonehara M (1989) A cell-killing monoclonal antibody (anti-Fas) to a cell surface antigen co-down-regulated with the receptor of tumor necrosis factor. J Exp Med 169: 1747-1756 